\title{
Role of the Structure of Humic Substances in Increasing Bacterial Survival
}

\section{Nikolaev YA ${ }^{1 *}$, Demkina EV ${ }^{1}$, Borzenkov IA ${ }^{1}$, Ivanova AE $^{1}$, Kanapatsky TA ${ }^{1}$, Konstantinov $\mathrm{AI}^{2}$, Volikov $\mathrm{AB}^{2}$, Perminova IV $^{2}$ and El-Registan GI ${ }^{1}$}

${ }^{1}$ Federal Research Center "Fundamentals of Biotechnology", Russian Academy of Sciences, Russia

${ }^{2}$ Faculty of Chemistry, Moscow State University, Russia

\section{Research Article \\ Volume 5 Issue 4}

Received Date: October 12, 2020

Published Date: October 28, 2020

DOI: 10.23880 /oajmb-16000174

*Corresponding author: Yu A Nikolaev, Federal Research Center "Fundamentals of Biotechnology”, Russian Academy of Sciences, Moscow, 119071, Russia, Tel: +79165231700; Email: NikolaevYA@mail.ru

\section{Abstract}

Humic substances (HSs) are important for the functioning and stability of soil ecosystems; their physical and chemical properties, as well as their influence on plants and animals are well studied. However, the role of HSs in the physiology of microorganisms, in particular, in their survival under unfavorable conditions, is understood insufficiently. To evaluate the role of various chemical groups and physicochemical properties of HSs in the survival of soil bacteria, experiments were performed using eight HS preparations with different structure and properties. Addition of HSs to cultures of hydrocarbonoxidizing soil bacteria Rhodococcus erythropolis and Pseudomonas extremaustralis increased the titers of viable cells after 30 days of storage up to 10 times. This biological effect of HSs is due to their ability to stimulate the formation of stress-resistant persister cells. Correlation analysis established a relationship between the biological activity of HS and the atomic content of hydrogen and carbon, hydrophobicity, and the average molecular weight of HS. The atomic content of oxygen, as well as the content of $\mathrm{CH}_{n}$ groups and various oxygen-containing groups $\left(\mathrm{CH}_{3} \mathrm{O}, \mathrm{CH}_{2} \mathrm{O}, \mathrm{CHO}, \mathrm{C}=\mathrm{O}\right.$, Alk-O) correlated with a negative effect of HS on bacterial viability. The content of aromatic groups and antioxidant capacity correlated with both activating and inhibiting biological activity of HSs. The stabilizing effect of HSs on bacterial cells is explained by their antioxidant activity, as well as by their ability to serve as a carbon source and to act as a terminal electron acceptor in the absence of oxygen. The obtained results elucidate an important function of HSs: to ensure long-term survival of bacteria in soil ecosystems in the periods between their active development.

Keywords: Humic Substances; Hydrocarbon-Oxidizing Bacteria; Increase of Viability; Biological Activity; Functional Group; Role of Humates in the Biosphere

Abbreviations: HS: Humic Substances; CFU: ColonyForming Unit; TH: Technoexport Humate; H7: Humate +7; GH: Gumicom Potassium Humate; PH: Powhumus Potassium Humate; SH: Sakhalin Humate; PSH: Peat-Sapropel Humate; LH: Lignohumate; FA: Fulvic Acids Fulvagra; NMR: Nucleic
Magnetic Resonance; ABE: Activating Biological Effect; IBE: Inhibiting Biological Effect; AOC: Antioxidant Capacity; TA: Total Aromatic Groups; CR: Column Recovery; Mw: The Average Molecular Mass of HS Preparation. 


\section{Open Access Journal of Microbiology \& Biotechnology}

\section{Introduction}

Humic substances (HSs) are a major component of natural organic matter that is not a part of living organisms, the mass of which significantly exceeds the mass of biota [1]. HSs can constitute up to $90 \%$ of organic matter present in soils and water bodies [2]. The chemical properties and composition of HSs, their physicochemical and structureforming role in soils $[3,4]$, and their functions in the biosphere, that is, accumulating metals and toxic compounds, serving as organic matter depots, and regulating physiological activity of plants and animals, are well studied [5]. The chemical composition of HSs is extremely complex, representing a continuum of individual chemical compounds that include all known chemical functional groups and have molecular masses ranging from hundreds to tens of thousands [6].

Since HSs are widely used in animal and plant breeding practice, their effects on plants and animals have been studied fairly well [7]. The influence of HSs on microorganisms is significantly less understood. It is known that HSs may serve as the only source of carbon and energy for bacterial growth [8] and may also act as electron acceptors during oxidation of organic and inorganic substrates [9-11]. A distinguishing property of HSs is the presence of numerous functional groups, including phenolic ones [3], which previously prompted us to investigate the influence of HSs on the formation of resting cells, an important aspect of microbial physiology $[12,13]$. HSs were found to increase the level of long-term survival of Acinetobacter junii cells by an order of magnitude, apparently by inducing the formation of persister cells $[14,15]$ that subsequently matured into resting cells [16], as well as due to antioxidant activity of HSs. A wider screening confirmed that all HS preparations tested increased the number of viable cells two- to tenfold [12]. However, it was not established what chemical and physicochemical properties of HS determine their ability to stabilize living bacteria, which became the goal of the present work.

\section{Materials and Methods}

\section{Cell Cultures and Bioassay Setup}

The study was performed using strains of gram-negative bacteria Pseudomonas extremaustralis and gram-positive bacteria Rhodococcus erythropolis that are able to actively oxidize oil hydrocarbons and utilize them as the only source of carbon and energy. The strains were obtained from the Uniqem Collection of Cultures (Federal Research Center of Biotechnology, Russian Academy of Sciences).

Bacteria were grown in 250-mL conical flasks containing $50 \mathrm{~mL}$ of liquid LB medium (AMRESCO) on an orbital shaker $(100 \mathrm{rpm})$ at $28 \pm 2^{\circ} \mathrm{C}$. Cultures in the stationary growth phase were used as inocula and introduced in the amount of $2 \%$ (vol.). The growth of cultures was assessed by their optical density at $\lambda=540 \mathrm{~nm}$ using a Jenway 7315 spectrophotometer (UK). The number of viable cells (CFU/ $\mathrm{mL}$ ) was determined by plating aliquots of sequential tenfold dilution of the cultures onto LB agar (1.8\% agar, Nelison).

\section{Humic Materials}

The study was performed using commercial preparations of humates and fulvic acids (Table 1), so as to ensure their stable quality and availability, taking into account that HS supply on the market of chemical reagents is rather limited.

HSs were dissolved in distilled water, filtered through a paper filter if necessary, autoclaved at $1 \mathrm{~atm}$, and then added to bacterial cultures to the final concentrations of $0.15,0.5$, and $1.5 \mathrm{~g} / \mathrm{L}$.

\begin{tabular}{|c|c|c|c|}
\hline No. & Product name (abbreviation) & Source & Manufacturer \\
\hline 1 & Technoexport humate & Brown coal & Technoexport Company, Ukraine \\
\hline 2 & Humate “+7" & Brown coal & Agrotechgumat, Irkutsk, Russia. \\
\hline 3 & Gumicom potassium humate & Brown coal & Emulsionnye tekhnologii, Samara, Russia \\
\hline 4 & Powhumus potassium humate & Leonardite (eroded brown coal) & Humintech Ltd, Germany \\
\hline 5 & Sakhalin humate & Leonardite (eroded brown coal) & Biomir 2000, Moscow, Russia \\
\hline 6 & Peat-sapropel humate & Peat and sapropel blend & Plodorodie, Galich, Russia \\
\hline 7 & Lignohumate & Lignosulfonate & RET Company, St. Petersburg, Russia \\
\hline 8 & Fulvic acids Fulvagra & Underground water & Humintech Ltd, Germany \\
\hline
\end{tabular}

Table 1: Humic substances preparations used in the study. 


\section{Open Access Journal of Microbiology \& Biotechnology}

\section{Structural Characterization of Humic Materials}

The elemental composition (CHNO) was determined on an automatic Vario EL CHN analyzer (Elementar). Structural group composition of HSs was determined by ${ }^{13} \mathrm{C}$ NMR spectroscopy in solution on an Avance 400 NMR spectrometer (Bruker) with a carrier frequency for ${ }^{13} \mathrm{C}$ nuclei of $100 \mathrm{MHz}$. HS samples (40-45 mg) were dissolved in 0.6 $\mathrm{mL}$ of $0.3 \mathrm{M} \mathrm{NaOD} / \mathrm{D}_{2} \mathrm{O}$. The solution was transferred into a 5 -mm ampoule for NMR, and the spectrum was recorded using the CPMG pulse sequence. The duration of the relaxation delay was $7.8 \mathrm{~s}$; the entire NMR experiment lasted for $10 \mathrm{~h}$. Quantitative ${ }^{13} \mathrm{C}$ NMR spectra were obtained using the conditions described in [17]. The spectra were processed using the MestReCb software as well as the GelTreat software developed by A.V. Kudryavtsev (Chemical Faculty of Moscow State University). The integration limits were selected according to Hertkorn, et al. [18] as follows (m.d.): 0-50 for $\mathrm{C}$ of alkyl groups, $\mathrm{CH}_{\mathrm{n}} ; 50-58$ for $\mathrm{C}$ of methoxy groups, $\mathrm{CH}_{3} \mathrm{O}$; 58-65 for $\mathrm{C}$ of alkoxy groups, $\mathrm{CH}_{2} \mathrm{O} ; 65-90$ for $\mathrm{C}$ of alkoxy groups, CHO; $90-110$ for $\mathrm{C}$ of acetal groups, OCO; 110-145 for aromatic $\mathrm{C}$ not substituted by heteroatoms, $\mathrm{C}_{\mathrm{ar}} ; 145-165$ for aromatic $\mathrm{C}$ substituted by heteroatoms, $\mathrm{C}_{\mathrm{ar}} \mathrm{O} ; 165-185$ for C of carboxyl groups, C00; 185-220 for C of carbonyl groups, $\mathrm{C}=\mathrm{O}$.

The average molecular mass of HS (Mw) was determined by size exclusion chromatography as described in Perminova, et al., $[19,20]$. Phosphate buffer $(0.03 \mathrm{M}, \mathrm{pH} 6.8)$ was used as the mobile phase. Analysis was performed using HS solutions in phosphate buffer with a concentration $\sim 80 \mathrm{mg} / \mathrm{L}$. Samples $(V=1 \mathrm{~mL})$ were loaded on the column $(D=0.15 \mathrm{~cm} ; L=25$ $\mathrm{cm})$ packed with the Toyopearl HW-55S resin. Calibration curves were obtained using sodium polystyrene sulfonates with known molecular masses: 80 840, 45 100, 33 500, 15800 , and $10200 \mathrm{Da}$. The analytical signal was recorded spectrophotometrically at $\lambda=254 \mathrm{~nm}$. The chromatograms were processed using the GelTreat software. The fraction of the substance yielded from the column (column recovery, CR) reflected the hydrophilicity of the HS tested.

\section{Antioxidant Activity of HS Preparations}

The antioxidant activity of humic preparations was assessed by the decrease in the concentration of 2.2'-azinodi-(3-ethylbenzothiazoline)-6-sulfonic acid (ABTS) (Sigma) diammonium salt in the reaction medium determined by spectrophotometry at $734 \mathrm{~nm}$ (Cary 50 spectrophotometer, Varian) and expressed in units of the equivalent concentration of trolox (6-hydroxy-2,5,7,8-tetramethylchroman-2carboxylic acid), a water-soluble analog of vitamin E. Antioxidant activity reflected the antioxidant capacity of the HSs tested in the presence of the ABTS oxidant under the given experimental conditions.

\section{Evaluation of the Biological Effects of HSs}

After both bacterial cultures reached the end of the linear growth phase (prestationary phase), various HSs (nos. 1-8, Table 1) were added in three concentrations: 0.15 , 0.5 and $1.5 \mathrm{~g} / \mathrm{L}$. The cultures were stored in test tubes for 30 days in the static mode at room temperature; next, the titers of viable cells (CFU/mL) were determined. The culture where no HS was added served as a control. For each HS preparation, the optimal concentration (with the highest $\mathrm{CFU} / \mathrm{mL}$ ) was identified, and the activating biological effect (ABE) was calculated as follows: the excessive number of $\mathrm{CFU} / \mathrm{mL}$ in comparison to the control was expressed in \% of the control CFU titer and normalized per $1 \mathrm{~g}$ of $\mathrm{HS}\left(\left(\mathrm{CFU}_{\text {exp }}\right)\right.$ $\left.\mathrm{CFU}_{\mathrm{c}}\right) /\left(\mathrm{CFU}_{\mathrm{c}} \times 100 \% / \mathrm{C}_{\mathrm{HS}}\right)$, where $\mathrm{CFU}_{\text {exp }}$ and $\mathrm{CFU}_{\mathrm{c}}$ - are $\mathrm{CFU}$ in experiment and control, $\mathrm{C}_{\mathrm{HS}}$ - is concentration of $\mathrm{HS}, \mathrm{g} / \mathrm{L}$ ). In case of inhibition, the inhibitory biological effect (IBE) of $\mathrm{HS}$ was calculated by subtracting the number of $\mathrm{CFU} / \mathrm{mL}$ in the experiment from the control value, expressing the result in $\%$ of control, and dividing it by the $\mathrm{HS}$ concentration in this experiment $\left(\left(\mathrm{CFU}_{c}-\mathrm{CFU}_{\text {exp }}\right) /\left(\mathrm{CFU}_{\mathrm{c}} \times 100 \% / \mathrm{C}_{\mathrm{HS}}\right)\right)$. The IBE value was calculated based on the highest inhibiting effect observed.

\section{Statistical Analysis}

The values of $\mathrm{ABE}$ and IBE were used to calculate the coefficients of Pearson ( $r$ ), Kendall, Gamma, and Spearman correlations between the biological effects of HS and the content of different functional groups in HSs or their other features. The approach to statistical processing and interpretation of the results was somewhat different from the standard based only on parametric statistics. In addition to the Pearson's parametric criterion $r$, the non-parametric Kendall, Gamma, and Spearman coefficients were employed, since the datasets used to calculate correlations did not conform to the normal distribution. The deviation of the data from the normal distribution was verified using the Statistica software and confirmed by discrepancy between the values of the mean, the median, and the mode. Finally, this is consistent with the literature insisting that the results of microbiological experiments should rather be described using Poisson statistics and/or non-parametric criteria [21].

A comparison of the correlation coefficients calculated in different ways showed that the Kendal and Gamma criteria were very nearly identical; therefore, the Kendal Tau criterion was not included in Tables 6-8. Our analysis of correlation coefficients revealed that it was only in a few cases that the significance of correlation was higher than 95\% (Tables 6-8). We found it necessary to consider also 


\section{Open Access Journal of Microbiology \& Biotechnology}

the correlation coefficients with significance levels lower than $95 \%$. This decision was based on several reasons. First, in terms of structure and molecular weight, humates are an extremely diverse set of compounds (continuum) in which the properties of any given chemical residue formally included in the indicator "carbon of a certain chemical group" (Table 5) are, strictly speaking, different; therefore, the dispersion of the data can be greater than for a single compound. Second, the use of formally calculated $p$-values to test null hypotheses in works on natural sciences is criticized by many researchers, considering that it often leads to first-kind errors (false positives) when the correct null hypothesis is rejected (in our case, it is the existence of correlation between two factors) and an alternative incorrect hypothesis is accepted [22-24]. The seriousness of this position is illustrated by the fact that some journals do not accept publications that use $p$-values [25]. It is proposed to replace $p$-values with alternative methods of providing evidence [23]. There is an ongoing heated discussion about the possible alternatives to using $p$-values [24]. Following common sense and calls for caution, we stepped back from the traditional 95\% significance threshold $(p<0.05)$ and took into account the correlations for which the confidence levels were greater than $50 \%(p<0.5)$, assuming that significance is the highest for $p<0.05$, fair for $0.05<p<0.1$, moderate for $0.1<p<0.2$, and possible for $0.2<p<0.5$. At the same time, all observed correlations were considered from the point of view of biological sense. When comparing three methods of calculation (Pearson, Gamma, and Spearman), priority was given to non-parametric criteria, because the samples used were not distributed normally.

All experiments were conducted in three biological replicates with three parallel independent measurements in each. The tables show the arithmetic mean values. The correlation coefficients were calculated using the Statistica software package (TIBCO Software inc., USA).

\section{Results}

\section{Effect of Humic Substances on Bacterial Survival}

The effect of HSs on bacterial survival was assessed by the CFU titers in cultures of hydrocarbon-oxidizing bacteria after 1 month of incubation. In 14 variants out of 24, addition of HSs led to a 2- to 11-fold increase in the CFU titer of $R$. erythropolis (Table 2). In one case, the number of CFU was 5 times lower than in the control, and in the remaining cases it was close to the control. For all HSs, the dependence between the biological effect and the HS concentration was nonlinear. The highest stimulating effect was observed for PH and FA, while the effects of GH were the lowest and even inhibitory.

\begin{tabular}{|c|c|c|c|c|c|c|c|c|}
\hline \multicolumn{9}{|c|}{ CFU (given as \% of HS-free control) } \\
\hline HS concentration, $\mathrm{g} / \mathrm{L}$ & SH & H7 & GH & PSH & $\mathrm{TH}$ & LH & FA & $\mathrm{PH}$ \\
\hline 0.15 & 232 & 321 & 20 & 88 & 638 & 621* & 100 & 1034* \\
\hline 0.5 & $357^{*}$ & 339* & $145^{*}$ & $357^{*}$ & 117 & 241 & 690 & 93 \\
\hline 1.5 & 339 & 75 & 77 & 196 & $897 *$ & 109 & $966^{*}$ & 119 \\
\hline \multicolumn{9}{|c|}{ Activating biological effect } \\
\hline & 714 & 679 & 289 & 714 & 598 & 4138 & 644 & 6893 \\
\hline
\end{tabular}

Table 2: Titers of viable R. erythropolis cells stored for 1 month in the presence of different HSs in comparison to the control and the activating biological effect of HS.

*- The maximal titers of viable cells are shown in bold.

Abbreviated headings are: CFU: colony-forming units titer. HS: humic substances. TH: Technoexport humate; H7: Humate +7; GH: Gumicom potassium humate; PH: Powhumus potassium humate; SH: Sakhalin humate; PSH: peat-sapropel humate; LH: Lignohumate; FA: fulvic acids.

For $P$. extremaustralis, the effects of HSs were heterogeneous (Table 3): an increase in CFU titers (2-10 times) was observed only in nine out of 24 variants, while in six cases the number of CFU/mL decreased two- to tenfold. At the same time, none of the HS preparations had a consistently negative effect on bacterial viability in all concentrations.
Based on the CFU data after 30 days of storage, the activating biological effects (ABE) of all HSs were calculated for both bacterial strains (Tables 2 and 3, bottom line), and the inhibiting biological effects (IBE) of HSs were calculated for P. extremaustralis (Table 3). 


\section{Open Access Journal of Microbiology \& Biotechnology}

\begin{tabular}{|c|c|c|c|c|c|c|c|c|}
\hline \multicolumn{9}{|c|}{ CFU (given as \% of HS-free control) } \\
\hline HS concentration, $\mathrm{g} / \mathrm{L}$ & SH & $\mathrm{H} 7$ & GH & PSH & $\mathrm{TH}$ & LH & FA & $\mathrm{PH}$ \\
\hline 0.15 & 92 & $\underline{28}$ & $\underline{23^{* *}}$ & $11^{* *}$ & $308^{*}$ & 88 & 91 & $487 *$ \\
\hline 0.5 & $1000^{*}$ & $217^{*}$ & $650^{*}$ & 54 & 87 & $372^{*}$ & $231^{*}$ & 282 \\
\hline 1.5 & 76 & $\underline{16^{* *}}$ & 133 & 142 & $\underline{53^{*}}$ & $50^{*}$ & $\underline{85^{*}}$ & 308 \\
\hline \multicolumn{9}{|c|}{ Activating biological effect } \\
\hline & 2000 & 433 & 1300 & 94 & 2051 & 744 & 462 & 3248 \\
\hline \multicolumn{9}{|c|}{ Inhibiting biological effect } \\
\hline & 16 & 480 & 513 & 593 & 31 & 33 & 10 & 0 \\
\hline
\end{tabular}

Table 3: Titers of viable $P$. extremaustralis cells stored for 1 month in the presence of HSs in comparison to the control and the activating and inhibiting biological effects of HS.

* - The maximal titers of viable cells are shown in bold;

** - the inhibition variants are underlined.

Abbreviated headings are: CFU: colony-forming units titer; HS: humic substances; TH: Technoexport humate; H7: Humate +7; GH: Gumicom potassium humate; PH: Powhumus potassium humate; SH: Sakhalin humate; PSH: peat-sapropel humate; LH: Lignohumate; FA: fulvic acids.

\section{Chemical, Physical and Physicochemical Properties of HSs}

Using the previously described techniques, the following characteristics of HSs were determined: the structural group composition as the fraction of carbon atoms belonging to particular chemical structures and groups $\left(\mathrm{CH}_{\mathrm{n}}\right.$ (alkyl), $\mathrm{CH}_{3} \mathrm{O}$ (methoxy), $\mathrm{CH}_{2} \mathrm{O}$ and $\mathrm{CHO}$ (alkoxy), OCO (anomeric groups of sugars), $\mathrm{C}_{\mathrm{ar}}$ (aromatic unsubstituted), $\mathrm{C}_{\mathrm{ar}} \mathrm{O}$ (aromatic substituted by heteroatoms), $\mathrm{COO}$ (carboxy), and $\mathrm{C}=0$ (carbonyl)); the elemental composition ( $\mathrm{C}-\mathrm{H}-\mathrm{N}-\mathrm{O})$; the molecular weight composition as the average molecular weight $\mathrm{M}_{\mathrm{w}}$; hydrophilicity as the degree of retention on the column determined by the output time delay; antioxidant capacity (AOC) (as ABTS equivalents) (Tables 4 and 5).

\begin{tabular}{|c|c|c|c|c|c|c|}
\hline \multirow{2}{*}{ HS } & \multirow{2}{*}{ Mw, kDa } & \multirow{2}{*}{ Column recovery } & \multicolumn{3}{|c|}{ CHNO data, atomic \% } \\
\cline { 4 - 8 } & & & $\mathbf{C}$ & $\mathbf{H}$ & $\mathbf{N}$ & $\mathbf{0}$ \\
\hline H7 & 10.2 & 41 & 41.99 & 3.58 & 0.72 & 53.72 \\
\hline SH & 12 & 69 & 50.9 & 4.11 & 1.9 & 43.1 \\
\hline TH & nd & nd & 56.69 & 3.97 & 1.73 & 37.61 \\
\hline PH & 12.7 & 43 & 62.75 & 4.4 & 0,99 & 31.87 \\
\hline LH & 11.4 & 57 & 43.1 & 4.67 & 0.37 & 51.65 \\
\hline FA & 6.4 & 96 & nd & nd & nd & nd \\
\hline
\end{tabular}

Table 4: Molecular mass and elemental composition of HS samples used in this study.

Abbreviated headings are: nd: not determined; HS: humic substances; TH: Technoexport humate; H7: Humate + 7; PH: Powhumus potassium humate; SH: Sakhalin humate; LH: Lignohumate; FA: fulvic acids; Mw, the average molecular mass of HS preparation

Based on their origin, the HS preparations analyzed can be divided into four classes: humates derived from oxidized brown coal (H7, GH, SH, TH, and PH), humates from sapropel and peat (PSH), fulvic acids of natural waters (FA), and oxidized lignin preparation (LH).

The highest content of alkyl moieties $\left(\mathrm{CH}_{n}\right)$ was observed for fulvic acids, as well as for the PSH preparation. The same preparations were characterized by the highest content of carboxyl groups and the lowest content of aromatic structures. Due to its origin, LH preparation was characterized by the lowest content of carboxylic carbon and the largest content of methoxy groups $\left(\mathrm{CH}_{3} \mathrm{O}\right)$ typical for lignin. It also had the highest content of oxidized aliphatic structures $\left(\mathrm{CH}_{2} \mathrm{O}\right.$ and $\left.\mathrm{CHO}\right)$ that reached a total of $21 \%$ and exceeded these values for fulvic acids (9.4\%) and sapropel humate (11\%). Lignin-derived humates had lower content of aromatic carbon unsubstituted with heteroatoms $\left(\mathrm{C}_{\mathrm{ar}}\right)$ than 


\section{Open Access Journal of Microbiology \& Biotechnology}

HSs obtained from eroded brown coal, but higher content of aromatic carbon substituted with heteroatoms $\left(\mathrm{C}_{\mathrm{ar}} \mathrm{O}\right)$. The exception was the GH preparation, which had the lowest content of aromatic carbon, both unsubstituted and replaced by heteroatoms, among the coal-derived humates.

\begin{tabular}{|c|c|c|c|c|c|c|c|c|c|c|}
\hline \multirow{2}{*}{$\mathbf{H S}$} & \multicolumn{7}{|c|}{ Distribution of C by structural fragments, \% of total C } \\
\cline { 2 - 13 } & $\mathbf{A O C}$ & $\mathbf{C H}_{\mathbf{n}}$ & $\mathbf{C H}_{\mathbf{3}} \mathbf{0}$ & $\mathbf{C H}_{\mathbf{2}} \mathbf{0}$ & $\mathbf{C H O}$ & $\mathbf{0 C O}$ & $\mathbf{C}_{\mathrm{ar}}$ & $\mathbf{C}_{\mathbf{a r}} \mathbf{0}$ & $\mathbf{C O O}$ & $\mathbf{C = 0}$ \\
\hline $\mathrm{GH}$ & 0.89 & 18.4 & 2.4 & 2.3 & 4.4 & 5.5 & 30.7 & 8.6 & 19 & 8.9 \\
\hline $\mathrm{H} 7$ & 0.65 & 12.7 & 2.5 & 1.7 & 2.2 & 4 & 44.5 & 13 & 13.5 & 5.9 \\
\hline $\mathrm{SH}$ & 1.24 & 11.4 & 1.5 & 1.3 & 3.6 & 4.5 & 41.8 & 10.5 & 19.4 & 6 \\
\hline $\mathrm{TH}$ & 0.69 & 12.2 & 2.2 & 0.9 & 6 & 4.8 & 40.9 & 12.2 & 13.4 & 7.3 \\
\hline $\mathrm{PH}$ & 0.71 & 14.9 & 1.9 & 1.1 & 2.8 & 4.6 & 42.1 & 9.9 & 15.8 & 6.8 \\
\hline $\mathrm{LH}$ & 1.91 & 7.4 & 7.2 & 5.5 & 15.6 & 3.7 & 37.1 & 14.9 & 3.8 & 4.8 \\
\hline PSH & 1.23 & 25.7 & 3.6 & 2.2 & 8.9 & 2.6 & 15.4 & 5.4 & 26.7 & 9.3 \\
\hline FA & 1.95 & 27.9 & 4.5 & 2.4 & 7 & 3.2 & 21.6 & 7.6 & 20.3 & 5.4 \\
\hline
\end{tabular}

Table 5: Structural group composition and antioxidant capacity of HS samples used in this study.

Abbreviated headings are: HS: humic substances; TH: Technoexport humate; H7: Humate +7; GH: Gumicom potassium humate; PH: Powhumus potassium humate; SH: Sakhalin humate; PSH: peat-sapropel humate; LH: Lignohumate; FA: fulvic acids; AOC: antioxidant capacity; $\mathrm{CHn}$ : alkyl groups; $\mathrm{CH}_{3} \mathrm{O}$ : methoxy groups; $\mathrm{CH}_{2} \mathrm{O}$ : alkoxy groups; $\mathrm{CHO}$ : alkoxy groups; OCO: acetal groups; Car: aromatic C not substituted by heteroatoms; CarO: aromatic C substituted by heteroatoms; COO: carboxyl groups; $\mathrm{C}=0$ : carbonyl groups.

In terms of molecular mass composition, fulvic acids differed from humates by lower values of molecular mass and much higher hydrophilicity, as determined by the yield of the substance from the chromatographic column. Among the humates of coal and oxidized lignin, the highest hydrophilicity was exhibited by the SH preparation, which is consistent with the relatively high content of carboxylic groups determined by NMR. It is also characterized by the lowest molecular mass value among coal humates. The oxidized lignin preparation had lower hydrophilicity than Sakhalin humate and higher than H7 coal preparation.

\section{Relationships between Structural Parameters and Biological Effects of HSs}

The Pearson's $r$, Spearman's $R$, and Gamma correlation coefficients for the activating effect of HSs (ABE) and various HS characteristics were calculated for both bacterial cultures studied (Tables 6 and 7). For gram-negative bacteria $P$. extremaustralis, correlations were also calculated for the inhibitory activity (IBE) (Table 8), since five out of eight HS preparations studied exhibited not only activating but also inhibitory effect on these bacteria, decreasing the number of viable cells two- to tenfold.

Distinct correlations suggesting positive or negative effects of different functional groups and physicochemical properties of HS on bacterial viability could be observed only for a small number of indicators. The molecular weight of HS and the fraction of hydrogen had a significant positive effect on the viability of $R$. erythropolis ( $p \leq 0.1$ ), and suggestive positive effects were obtained for the fraction of carbon and hydrophilicity/hydrofobicity $(p<0.5)$. Suggestive negative effects on ABE (negative correlation coefficients at $p<0.5$ ) were observed for oxygen content, groups $\mathrm{CH}_{\mathrm{n}}, \mathrm{OCO}, \mathrm{C}=\mathrm{O}$, and total aromatic groups.

When analyzing the influence of different HS groups and properties on the viability of $P$. extremaustralis, the effect of a given parameter was considered positive if the correlation coefficient was positive in the analysis of $\mathrm{ABE}$ and the correlation coefficient was negative in the analysis of IBE (Tables 7 and 8). Molecular weight, hydrophobicity, specific content of $\mathrm{C}$, and content of OCO groups had a significant positive effect on the survival of $P$. extremaustralis ( $p \leq 0.05$ ); a suggestive positive biological effect was observed for the hydrogen content. Negative effects were significantly associated with oxygen content and exhibited suggestive association with the content of the $\mathrm{CH}_{\mathrm{n}}, \mathrm{CH}_{3} \mathrm{O}, \mathrm{CH}_{2} \mathrm{O}, \mathrm{CHO}$, $\mathrm{C}=0$, and Alk-O groups $(p<0.5)$. Antioxidant capacity and the content of aromatic groups exhibited both positive and negative moderate correlations with survival rates of P. extremaustralis. 


\section{Open Access Journal of Microbiology \& Biotechnology}

\begin{tabular}{|c|c|c|c|c|c|c|}
\hline & \multicolumn{2}{|c|}{ Pearson } & \multicolumn{2}{c|}{ Spearman } & \multicolumn{2}{c|}{ Gamma } \\
\hline & $\mathrm{r}$ & $\boldsymbol{p}$ & $\boldsymbol{R}$ & $\boldsymbol{p}$ & Gamma & $\boldsymbol{p}$ \\
\hline $\mathrm{AOC}$ & 0.02 & 0.98 & 0.18 & 0.67 & 0.11 & 0.71 \\
\hline $\mathrm{CH}_{\mathrm{n}}$ & 0.21 & 0.79 & $\mathbf{- 0 . 3 2}$ & $\mathbf{0 . 4 3}$ & $\mathbf{- 0 . 2 6}$ & $\mathbf{0 . 3 8}$ \\
\hline $\mathrm{CH}_{3} \mathrm{O}$ & 0.21 & 0.79 & -0.01 & 0.98 & 0.04 & 0.90 \\
\hline $\mathrm{CH}_{2} \mathrm{O}$ & 0.14 & 0.86 & -0.02 & 0.96 & -0.04 & 0.90 \\
\hline $\mathrm{CHO}$ & 0.22 & 0.78 & 0.02 & 0.96 & 0.11 & 0.71 \\
\hline $\mathrm{OCO}$ & 0.18 & 0.82 & $\mathbf{- 0 . 3 8}$ & $\mathbf{0 . 3 5}$ & $\mathbf{- 0 . 2 6}$ & $\mathbf{0 . 3 8}$ \\
\hline $\mathrm{Alk}-\mathrm{O}$ & 0.21 & 0.79 & -0.11 & 0.80 & -0.04 & 0.90 \\
\hline $\mathrm{C}_{\mathrm{ar}}$ & -0.37 & 0.63 & 0.28 & 0.51 & 0.19 & 0.53 \\
\hline $\mathrm{C} \mathrm{a}$ & -0.19 & 0.81 & 0.19 & 0.65 & 0.11 & 0.71 \\
\hline $\mathrm{COO}$ & -0.26 & 0.74 & -0.10 & 0.82 & -0.04 & 0.90 \\
\hline $\mathrm{C}=\mathrm{O}$ & 0.28 & 0.72 & $\mathbf{- 0 . 2 9}$ & $\mathbf{0 . 4 9}$ & -0.19 & 0.53 \\
\hline $\mathrm{TA}$ & $\mathbf{- 0 . 5 8}$ & $\mathbf{0 . 4 2}$ & -0.02 & 0.95 & -0.08 & 0.80 \\
\hline $\mathrm{M} \mathrm{C}$ & $\mathbf{0 . 6 7}$ & $\mathbf{0 . 3 3}$ & $\mathbf{0 . 9 0}$ & $\mathbf{0 . 0 4}$ & $\mathbf{0 . 8 0}$ & $\mathbf{0 . 0 5}$ \\
\hline $\mathrm{CR}$ & -0.36 & 0.64 & $\mathbf{- 0 . 4 0}$ & $\mathbf{0 . 5 0}$ & $\mathbf{- 0 . 4 0}$ & $\mathbf{0 . 3 3}$ \\
\hline $\mathrm{C}$ & $\mathbf{0 . 6 8}$ & $\mathbf{0 . 3 2}$ & 0.30 & 0.62 & 0.20 & 0.62 \\
\hline $\mathrm{H}$ & $\mathbf{0 . 7 1}$ & $\mathbf{0 . 2 9}$ & $\mathbf{0 . 8 0}$ & $\mathbf{0 . 1 0}$ & $\mathbf{0 . 6 0}$ & $\mathbf{0 . 1 4}$ \\
\hline $\mathrm{N}$ & -0.36 & 0.64 & -0.30 & 0.62 & -0.20 & 0.62 \\
\hline $\mathrm{O}$ & $\mathbf{0 . 6 6}$ & $\mathbf{0 . 3 4}$ & -0.30 & 0.62 & -0.20 & 0.62 \\
\hline
\end{tabular}

Table 6: Correlations between HS characteristics and their ABE in R. erythropolis as assessed using the Pearson $(r)$, Spearman $(R)$, and gamma (Gamma) correlation coefficients. For each value, the level of significance $(p)$ is provided.

Abbreviated headings are: AOC: antioxidant capacity; TA: total aromatic groups; CR: column recovery; $\mathrm{CHn}$ : alkyl groups; $\mathrm{CH}_{3} \mathrm{O}$ : methoxy groups; $\mathrm{CH}_{2} \mathrm{O}$ : alkoxy groups; $\mathrm{CHO}$ : alkoxy groups; OCO: acetal groups; $\mathrm{C}_{\mathrm{ar}}$, aromatic $\mathrm{C}$ not substituted by heteroatoms; $\mathrm{C}_{\mathrm{ar}} \mathrm{O}$ : aromatic $\mathrm{C}$ substituted by heteroatoms; COO: carboxyl groups; $\mathrm{C}=\mathrm{O}$, carbonyl groups.

\begin{tabular}{|c|c|c|c|c|c|c|}
\hline & \multicolumn{2}{|c|}{ Pearson } & \multicolumn{2}{c|}{ Spearman } & \multicolumn{2}{c|}{ Gamma } \\
\hline & $\mathrm{r}$ & $\mathrm{p}$ & $\boldsymbol{R}$ & $\boldsymbol{p}$ & Gamma & $\boldsymbol{p}$ \\
\hline $\mathrm{AOC}$ & $\mathbf{- 0 . 4 8}$ & $\mathbf{0 . 2 3}$ & -0.21 & 0.61 & $\mathbf{0 . 2 1}$ & $\mathbf{0 . 4 6}$ \\
\hline $\mathrm{CH}_{n}$ & $\mathbf{- 0 . 4 1}$ & $\mathbf{0 . 3 1}$ & $\mathbf{- 0 . 3 8}$ & $\mathbf{0 . 3 5}$ & $\mathbf{- 0 . 2 1}$ & $\mathbf{0 . 4 6}$ \\
\hline $\mathrm{CH}_{3} \mathrm{O}$ & $\mathbf{- 0 . 5 5}$ & $\mathbf{0 . 1 6}$ & $\mathbf{- 0 . 7 1}$ & $\mathbf{0 . 0 5}$ & $\mathbf{- 0 . 5 0}$ & $\mathbf{0 . 0 8}$ \\
\hline $\mathrm{CH}_{2} \mathrm{O}$ & $\mathbf{- 0 . 4 8}$ & $\mathbf{0 . 2 2}$ & $\mathbf{- 0 . 6 0}$ & $\mathbf{0 . 1 2}$ & $\mathbf{- 0 . 4 3}$ & $\mathbf{0 . 1 4}$ \\
\hline $\mathrm{CHO}$ & $\mathbf{- 0 . 4 3}$ & $\mathbf{0 . 2 8}$ & $\mathbf{- 0 . 3 3}$ & $\mathbf{0 . 4 2}$ & $\mathbf{- 0 . 2 9}$ & $\mathbf{0 . 3 2}$ \\
\hline $\mathrm{OCO}$ & $\mathbf{0 . 6 7}$ & $\mathbf{0 . 0 7}$ & $\mathbf{0 . 7 6}$ & $\mathbf{0 . 0 3}$ & $\mathbf{0 . 5 7}$ & $\mathbf{0 . 0 5}$ \\
\hline $\mathrm{Alk}-\mathrm{O}$ & $\mathbf{- 0 . 4 8}$ & $\mathbf{0 . 2 3}$ & $\mathbf{- 0 . 5 7}$ & $\mathbf{0 . 1 4}$ & $\mathbf{- 0 . 4 3}$ & $\mathbf{0 . 1 4}$ \\
\hline $\mathrm{C}_{\mathrm{ar}}$ & $\mathbf{0 . 6 0}$ & $\mathbf{0 . 1 1}$ & 0.45 & 0.26 & $\mathbf{0 . 4 3}$ & $\mathbf{0 . 1 4}$ \\
\hline $\mathrm{C}_{\mathrm{ar}} \mathrm{O}$ & 0.18 & 0.68 & 0.24 & 0.57 & $\mathbf{0 . 2 1}$ & $\mathbf{0 . 4 6}$ \\
\hline $\mathrm{COO}$ & -0.15 & 0.72 & $\mathbf{- 0 . 3 8}$ & $\mathbf{0 . 3 5}$ & $\mathbf{- 0 . 2 9}$ & $\mathbf{0 . 3 2}$ \\
\hline $\mathrm{TA}$ & -0.01 & 0.99 & 0.07 & 0.87 & 0.00 & 1.00 \\
\hline $\mathrm{M} \mathrm{C}$ & $\mathbf{0 . 5 2}$ & $\mathbf{0 . 1 8}$ & $\mathbf{0 . 3 6}$ & $\mathbf{0 . 3 8}$ & $\mathbf{0 . 3 3}$ & $\mathbf{0 . 2 6}$ \\
\hline $\mathrm{CR}$ & $\mathbf{0 . 7 0}$ & $\mathbf{0 . 1 9}$ & $\mathbf{0 . 9 0}$ & $\mathbf{0 . 0 4}$ & $\mathbf{0 . 8 0}$ & $\mathbf{0 . 0 5}$ \\
\hline $\mathrm{C}$ & -0.36 & 0.56 & 0.10 & 0.87 & 0.00 & 1.00 \\
\hline $\mathrm{H}$ & $\mathbf{0 . 9 8}$ & $\mathbf{0 . 0 0}$ & $\mathbf{1 . 0 0}$ & $\mathbf{0 . 0 0}$ & $\mathbf{1 . 0 0}$ & $\mathbf{0 . 0 1}$ \\
\hline $\mathrm{N}$ & 0.28 & 0.64 & 0.30 & 0.62 & 0.20 & 0.62 \\
\hline $\mathrm{O}$ & $\mathbf{0 . 5 0}$ & $\mathbf{0 . 3 9}$ & 0.50 & 0.39 & 0.20 & 0.62 \\
\hline
\end{tabular}

Table 7: Correlations between HS characteristics and their ABE in $P$. extemaustralis as assessed using the Pearson $(r)$, Spearman $(R)$, and gamma (Gamma) correlation coefficients. For each value, the level of significance $(p)$ is provided.

Abbreviated headings are: AOC: antioxidant capacity; TA: total aromatic groups; CR: column recovery; CHn: alkyl groups; $\mathrm{CH}_{3} \mathrm{O}$ : methoxy groups; $\mathrm{CH}_{2} \mathrm{O}$ : alkoxy groups; $\mathrm{CHO}$ : alkoxy groups; OCO: acetal groups; $\mathrm{C}_{\mathrm{ar}}$, aromatic $\mathrm{C}$ not substituted by heteroatoms; $\mathrm{C}_{\mathrm{ar}} \mathrm{O}$ : aromatic $\mathrm{C}$ substituted by heteroatoms; $\mathrm{COO}$ : carboxyl groups; $\mathrm{C}=\mathrm{O}$ : carbonyl groups. 


\section{Open Access Journal of Microbiology \& Biotechnology}

\begin{tabular}{|c|c|c|c|c|c|c|}
\hline & \multicolumn{2}{|c|}{ Pearson } & \multicolumn{2}{c|}{ Spearman } & \multicolumn{2}{c|}{ Gamma } \\
\hline & $\mathrm{r}$ & $\mathrm{p}$ & $\mathrm{R}$ & $\boldsymbol{p}$ & Gamma & $\boldsymbol{p}$ \\
\hline $\mathrm{AOC}$ & -0.54 & 0.63 & $\mathbf{- 0 . 5 8}$ & $\mathbf{0 . 1 8}$ & $\mathbf{- 0 . 4 0}$ & $\mathbf{0 . 2 2}$ \\
\hline $\mathrm{CH}_{\mathrm{n}}$ & 0.32 & 0.79 & 0.18 & 0.70 & $\mathbf{0 . 3 0}$ & $\mathbf{0 . 3 6}$ \\
\hline $\mathrm{CH}_{3} \mathrm{O}$ & 0.09 & 0.94 & 0.02 & 0.97 & 0.10 & 0.76 \\
\hline $\mathrm{CH}_{2} \mathrm{O}$ & 0.00 & 1.00 & -0.04 & 0.94 & 0.00 & 1.00 \\
\hline $\mathrm{CHO}$ & -0.18 & 0.88 & 0.02 & 0.97 & 0.00 & 1.00 \\
\hline $\mathrm{OCO}$ & -0.57 & 0.61 & 0.02 & 0.97 & 0.10 & 0.76 \\
\hline $\mathrm{Alk}-\mathrm{O}$ & -0.09 & 0.95 & 0.13 & 0.79 & 0.10 & 0.76 \\
\hline $\mathrm{C}_{\mathrm{ar}}$ & 0.44 & 0.71 & -0.23 & 0.61 & $\mathbf{- 0 . 2 0}$ & $\mathbf{0 . 5 4}$ \\
\hline $\mathrm{C} \mathrm{O}$ & 0.50 & 0.67 & -0.18 & 0.70 & -0.10 & 0.76 \\
\hline $\mathrm{COO}$ & -0.29 & 0.81 & 0.09 & 0.85 & 0.10 & 0.76 \\
\hline $\mathrm{C}=\mathrm{O}$ & -0.03 & 0.98 & $\mathbf{0 . 6 8}$ & $\mathbf{0 . 0 9}$ & $\mathbf{0 . 6 0}$ & $\mathbf{0 . 0 6}$ \\
\hline $\mathrm{TA}$ & $\mathbf{0 . 8 8}$ & $\mathbf{0 . 3 1}$ & -0.18 & 0.70 & -0.10 & 0.76 \\
\hline $\mathrm{Mw}$ & $\mathbf{- 0 . 9 9}$ & $\mathbf{0 . 0 7}$ & 0.20 & 0.80 & 0.00 & 1.00 \\
\hline $\mathrm{CR}$ & $\mathbf{- 1 . 0 0}$ & $\mathbf{0 . 0 0}$ & $\mathbf{- 1 . 0 0}$ & $\mathbf{0 . 0 0}$ & $\mathbf{- 1 . 0 0}$ & $\mathbf{0 . 0 4}$ \\
\hline $\mathrm{C}$ & $\mathbf{0 . 8 9}$ & $\mathbf{0 . 3 0}$ & $\mathbf{- 0 . 6 3}$ & $\mathbf{0 . 3 7}$ & $\mathbf{- 0 . 6 0}$ & $\mathbf{0 . 2 6}$ \\
\hline $\mathrm{H}$ & -0.56 & 0.62 & $\mathbf{- 0 . 6 3}$ & $\mathbf{0 . 3 7}$ & $\mathbf{- 0 . 6 0}$ & $\mathbf{0 . 2 6}$ \\
\hline $\mathrm{N}$ & $\mathbf{- 0 . 6 8}$ & $\mathbf{0 . 5 3}$ & $\mathbf{- 0 . 6 3}$ & $\mathbf{0 . 3 7}$ & $\mathbf{- 0 . 6 0}$ & $\mathbf{0 . 2 6}$ \\
\hline $\mathrm{O}$ & $\mathbf{0 . 9 1}$ & $\mathbf{0 . 2 7}$ & $\mathbf{0 . 6 3}$ & $\mathbf{0 . 3 7}$ & $\mathbf{0 . 6 0}$ & $\mathbf{0 . 2 6}$ \\
\hline
\end{tabular}

Table 8: Correlations between HS characteristics and their IBE in $P$. extemaustralis as assessed using the Pearson $(r)$, Spearman $(R)$, and gamma (Gamma) correlation coefficients. For each value, the level of significance $(p)$ is provided.

Abbreviated headings are: AOC: antioxidant capacity; TA: total aromatic groups; CR: column recovery; $\mathrm{CHn}$ : alkyl groups; $\mathrm{CH}_{3} \mathrm{O}$ : methoxy groups; $\mathrm{CH}_{2} \mathrm{O}$ : alkoxy groups; $\mathrm{CHO}$ : alkoxy groups; OCO: acetal groups; $\mathrm{C}_{\mathrm{ar}}$, aromatic $\mathrm{C}$ not substituted by heteroatoms; $\mathrm{C}_{\mathrm{ar}} \mathrm{O}$ : aromatic $\mathrm{C}$ substituted by heteroatoms; COO: carboxyl groups; $\mathrm{C}=\mathrm{O}$, carbonyl groups.

\section{Discussion}

The present work was undertaken based on the assumption that HS may exhibit stress-protective activity thanks to high content of phenolic components that represent chemical analogs of microbial autoregulators of resting cells formation, stress response, and density regulation, such as alkylresorcinols [26]. The obtained results support fairly well the hypothesis about the potential stress-protective action of HS. In particular, it was found that, for all HSs tested, their addition during long-term storage of hydrocarbonoxidizing bacteria increased the titers of viable cells 2-10 times, depending on the concentration (Tables 2 and 3 ).

However, in some cases, HS were also observed to have an inhibitory effect. For example, at certain concentrations, GH caused more than $50 \%$ inhibition in $R$. erythropolis, and so did H7, GH, PSH, TH and LH in P. extremaustralis. The effects of SH, $\mathrm{PH}$, and FA in both bacterial strains were only activating (without strong inhibition) (Tables 2 and 3). Such a dual "activation/inhibition" effect depending on the substance concentration is also typical for natural bacterial phenolic autoregulators [27].

For both bacterial species, unambiguous correlations between the characteristics of HSs and their biological effects were obtained only for the elemental composition and the molecular weight: higher carbon and hydrogen fractions corresponded to greater biological activity (with correlation coefficients of up to 0.98), while the correlation with the oxygen fraction was negative $(r=-0.7$ to $r=-1)$. No clear dependence of biological activity on the nitrogen fraction was revealed. The mean molecular weight $\left(\mathrm{M}_{\mathrm{w}}\right)$ ranged from 6 to $12.7 \mathrm{kDa}$, and a greater weight corresponded to a higher activating biological effect with $r=0.7-0.99$.

As for the role of chemical groups, it was only aromatic substituents and anomeric structures (OCO) corresponding to sugar groups that exhibited a positive correlation with the effect of HSs on P. extremaustralis. This confirms our initial hypothesis about the importance of oxidized phenols for stabilization of bacterial cells during their storage. There are several reasons why the stimulating effect of these HS features is an expected finding. First, sugars can be used by microorganisms as carbon sources at the stage of resting cells maturation, andutilization ofHSs as the solecarbon sourcewas demonstrated for soil microorganisms [8]. Second, aromatic groups are responsible for the donor/acceptor properties of HSs, i.e., their antioxidant and pro-oxidant activity [7]. Third, a high hydrogen and carbon content reflects a high degree of HS reduction and their elevated antioxidant activity. These conclusions are consistent with the fact that the stimulating 


\section{Open Access Journal of Microbiology \& Biotechnology}

effect of HS correlated negatively with the content of oxygen and oxidized groups $\left(\mathrm{C}=\mathrm{O}\right.$ for both bacteria and $\mathrm{CH}_{3} \mathrm{O}, \mathrm{CH}_{2} \mathrm{O}$, CHO, AlkO for P. extremaustralis). Obviously, highly oxidized HSs have less pronounced antioxidant properties.

The relationship between the antioxidant capacity of HSs and their activating or inhibitory effects was ambivalent: for P. extremaustralis, AOC had a positive correlation with both $\mathrm{ABE}$ and IBE. However, our previous work demonstrated a clear direct correlation between $\mathrm{AOC}$ and the positive biological effects of HSs on the viability of Acinetobacter junii cultures [13]. This apparent controversy in the effects of the antioxidant capacity of HSs can be explained using the broader notion of "antioxidant activity", which is determined not only by the number of electrons that can be donated/accepted by a particular compound (its "antioxidant capacity"), but also by its red/ox potential (Eh) under given conditions. Obviously, under microaerobic conditions of bacterial cultures storage, HSs could also have exhibited prooxidant properties, which are typical for them $[10,28,11,9]$. Sustained metabolic activity is important for the maturation of persister cells into resting cells, and it was ensured by the presence of HSs. At the same time, excessive oxidative activity of HSs could have a negative impact on cell survival. In our previous work, storage experiments were performed with older cultures for which the maintenance of metabolism was no longer critical, while the role of antioxidant activity was more significant; as a consequence, a positive correlation was observed between AOC and the stimulating effect of HS [13].

Similarly to AOC, the content of aromatic groups also had ambivalent effects: we observed a negative effect on the survival of $R$. erythropolis and both positive and negative effects on the survival of $P$. extremaustralis (Tables 7 and 8). This effect of aromatic groups is explained by their high donor/acceptor activity: the ability to act as both pro- and antioxidants, depending on the environmental conditions.

The positive effect of molecular weight can be explained by the fact that lighter amphiphilic molecules can penetrate more easily through the cell membrane into the cytoplasm and induce an inhibitory effect. For example, it was shown previously that low-molecular-weight HSs had a pronounced genotoxic effect [29], as well as that light HSs with a mass of $\sim 1000$ Da trigger redox reactions in seed cells.

The correlation between HS hydrophobicity and their ABE is explained by the presence of hydrophobic sites in the cell walls of bacteria, especially gram-positive R. erythropolis, which facilitates the penetration of HSs into the cell walls of bacteria and promotes their biological activity. Furthermore, we assume that the HS effect on bacteria is mediated by the cell membranes (since the high molecular weight of HS prevents them from entering the cell). In this case, the interaction with the membrane, a hydrophobic structure, is facilitated for HSs with elevated hydrophobicity. The interaction with the cell via the membrane is another common feature that HSs share with alkylresorcinols, which proves the similarity of their biological functions [30].

Based on the available data, it is difficult to explain the negative effect of the content of aliphatic $\mathrm{CH}_{n}$ groups on the survival of microbial cultures. This issue should be addressed in further studies of HS influence on the physiology of microorganisms. It is also difficult to say clearly why HSs had a uniform effect on gram-positive bacteria and at the same time their influence on Gram-negative bacteria was ambivalent. This phenomenon will be investigated and explained in the future. However, it should already be taken into account when choosing HS additives to increase the titer of surviving cells during storage. Both the concentration and the type of HS should be selected considering the responses of each given microorganism.

Prior to our research, it was known that HSs could serve a source of carbon and energy for bacteria [8] and that they could participate in redox reactions, both as electron donors and acceptors $[10,28,11,9]$. The data presented in this paper reveal a further important role of HS: to ensure the survival of bacteria in the periods when growth is prevented by unfavorable conditions (e.g., cold or draught), as well as the survival of parasitic microorganisms outside of the host organism, in soil. The mechanism of such action of HS is based on the induction of persister cells that mature into resting cells $[12,13]$. HSs can induce persister formation thanks to the presence of aromatic groups, similarly to alkyloxybenzenes, autoregulators of resting cells formation in microorganisms [31]. These compounds (alkyloxybenzenes) are usual components of plants [32] and may be readily found in soils [33].

The obtained results are consistent with the reported positive effect of HSs on the intestinal microbiota of humans [34] and animals [35,36], which probably occurs due to prevention of bacterial stress and more effective formation of resting cells.

\section{Conclusion}

The results of this study invite the conclusion that HSs increase the survival of bacteria in soil under unfavorable conditions, during the periods when growth is impossible. Using the hydrocarbon-oxidizing soil bacteria R. erythropolis and P. extremaustralis, it was demonstrated that the titer of cells that survived for 30 days increased up to 11 times in the presence of different HSs. The biological effect of HSs is explained by their ability to stimulate the formation of stressresistant persister cells. Increased viability of bacterial 
cells during storage correlated directly with the specific content of $\mathrm{C}$ and $\mathrm{H}$ atoms, the average molecular weight of HSs, and hydrophobicity of HSs, and at the same time had a negative correlation with the specific content of oxygen atoms, as well as $\mathrm{CH}_{\mathrm{n}}$ and $\mathrm{C}=0$ groups. The biochemical mechanisms underlying the observed cell-stabilizing effects of HSs are their membranotropic action (hydrophobicity) and antioxidant activity, their ability to serve as a source of carbon and energy, and probably the ability to act as electron acceptors in the absence of oxygen. The obtained data can be used to stabilize biopreparations containing various bacteria for the purposes of biotechnological applications.

\section{Funding}

This study was supported by the Russian Foundation for Basic Research (grant no. 18-29-05009) and partially financed by the Ministry of Science and Higher Education of the Russian Federation.

\section{Compliance with Ethical Standards}

This article does not contain any studies involving animals or human participants.

\section{References}

1. Jorgensen SE, Svirezhev YM (2004) Towards a Thermodynamic Theory for Ecological Systems. Elsevier, Science, pp: 380.

2. Thurman EM (1985) Amount of organic carbon in natural waters. Organic geochemistry of natural waters. Developments in Biogeochemistry, V.2. Springer, Dordrecht, pp: 7-65.

3. Stevenson FJ (1994) Humus Chemistry: Genesis, Composition, Reactions, $2^{\text {nd }}($ Edn.), Wiley, New York, pp: 512.

4. Volikov AB, Ponomarenko SA, Gutsche A, Nirschl H, Hatfield K, et al. (2016) Targeted design of water-based humic substances-silsesquioxane soft materials for nature-inspired remedial applications. RSC advances 6: 48222-48230.

5. Kulikova N, Stepanova E, Koroleva O (2005) Mitigating Activity of Humic Substances: Direct Influence on Biota. In: Perminova IV, Hatfield K, Hertkorn N, (Eds.), Use of Humic Substances to Remediate Polluted Environments: From Theory to Practice. NATO Science Series (Series IV: Earth and Environmental Series), 52, Springer, Dordrecht.
6. Piccolo A (2001) The supramolecular structure of humic substances: A novel understanding of humus chemistry and implications in soil science. Advances in Agronomy 166(11): 810-832.

7. Kondratenko EP, Sukhikh AS, Verbitskaia NV, Soboleva OM (2016) Biostimulation and physicochemical properties of sodium humate. Chemistry of plant raw material 3: 109-118.

8. Tikhonov VV, Yakusheva AV, Zavgorodnyaya YuA, Byzov BA, Demin VV (2010) Effects of Humic Acids on the Growth of Bacteria. Eurasian Soil Science 43(3): 305313.

9. Lovley DR, Coates JD, Blunt-Harris EL, Phillips EJP, Woodward JC (1996) Humic substances as electron acceptors for microbial respiration. Nature 382: 445448.

10. Klüpfel L, Piepenbrock A, Kappler A, Sander M (2014) Humic substances as fully regenerable electron acceptors in recurrently anoxic environments. Nature Geoscience 7: 195-200.

11. Bai YN, Wang XN, Wu J, Lu YZ, Fu L, et al. (2019) Humic substances as electron acceptors for anaerobic oxidation of methane driven by ANME-2d. Water Res 164: 114935.

12. Nikolaev YA, Demkina EV, Loiko NG, Borzenkov IA, Ivanona AE, et al. (2019) Role of humic compounds in viability prolongation of the cells of hydrocarbonoxidizing bacteria. Microbiology 88(6): 764-768.

13. Nikolaev YA, Loiko NG, Demkina EV, El'-Registan GI, Konstantinov AI, et al. (2020) Functional activity of humic substances in survival prolongation of populations of hydrocarbon-oxidizing bacteria Acinetobacter junii. Microbiology 89(1): 74-85.

14. Lewis K (2010) Persister cells. Annu Rev Microbiol 64: 357-372.

15. Balaban NQ, Gerdes K, Lewis K, McKinney JD (2013) A problem of persistence: still more questions than answers. Nat Rev Microbiol 11(8): 587-591.

16. Loiko NG, Kozlova AN, Nikolaev YA, Gaponov AM, Tutel'yan AV, et al. (2015) Effect of stress on emergence of antibiotic-tolerant Escherichia coli cells. Microbiologiia 84(5): 512-528.

17. Kovalewsky DV, Permin AB, Perminova IV, Petosyan VS (2000) Selection of conditions for recording quantitative 13C NMR spectra of humic acids. Moscow University Chemistry Bulletin (Chemistry). 41(1): 39-42. 
18. Hertkorn N, Permin AB, Perminova I, Kovalevskii D, Yudov M, et al. (2002) Comparative Analysis of Partial Structures of a Peat Humic and Fulvic Acid using One and Two Dimensional Nuclear Magnetic Resonance Spectroscopy. J Environ Qual 31(2): 375-387.

19. Perminova IV, Frimmel FH, Kovalevskii DV, Abbt-Braun G, Kudryavtsev AV, et al. (1998) Depelopment of a predictive model for calculation of molecular weight of humic substances. Wat Res 32(3): 872-881.

20. Perminova IV, Frimmel FH, Kudryavtsev AV, Kulikova NA, Abbt-Braun G, et al. (2003) Molecular weight characteristics of humic substances from different environments as determined by size exclusion chromatography and their statistical evaluation. Environ Sci Technol 37(11): 2477-2485.

21. Paulson DS (2008) Biostatistics and Microbiology: A Survival Manual. Springer, New York.

22. Johnson DH (1999) The Insignificance of Statistical Significance Testing. Journal of Wildlife Management 63(3): 763-772.

23. Wasserstein RL, Lazar NA (2016) The ASA's statement on p-values: context, process, and purpose. The American Statistician 70(2): 129-133.

24. Amrhein V, Greenland S, McShane B (2019) Retire statistical significance. Nature 567: 305-307.

25. Woolston C (2015) Psychology journal bans $P$ values. Nature News 519(7541): 9-9.

26. El-Registan GI, Mulyukin AL, Nikolaev YA, Gal'chenko VF, Suzina NE, etal. (2006) Adaptive functions of extracellular autoregulators of microorganisms. Microbiologiia 75(4): 446-456.

27. Nikolaev LA, Loiko NG, Stepanenko L, Shanenko EF, Martirosova EI, et al. (2008) Changes in physicochemical properties of proteins, caused by modification with alkylhydroxybenzenes. Prikl Biokhim Mikrobiol 44(2):159-167.
28. Aeschbacher M, Graf C, Schwarzenbach RP, Sander M (2012) Antioxidant Properties of Humic Substances. Environ Sci Technol 46(9): 4916-4925.

29. Yakimenko OS, Terekhova VA (2011) Humic Preparations and the Assessment of Their Biological Activity for Certification Purposes. Eurasian Soil Science 44(11): 1222-1230.

30. Kaprelyants AS, Suleimenov MK, Sorokina AD, Deborin GA, El-Registan GI, et al. (1987) Structural and functional changes in bacterial and model cell membranes under phenolic lipids actions. Biological membranes 4: 254262.

31. Stasiuk M, Kozubek A (2010) Biological activity of phenolic lipids. Cell Mol Life Sci 67(6): 841-860.

32. Lin D, Xiao M, Zhao J, Li Z, Xing B, etal. (2016) An Overview of Plant Phenolic Compounds and Their Importance in Human Nutrition and Management of Type 2 Diabetes. Molecules 21(10): 1374.

33. Pernica M, Lesniaková R, Doležalová D, Šimek Z (2019) Analysis of alkylphenols and bisphenols in soils using liquid chromatography-tandem mass spectrometry. International Journal of Environmental Analytical Chemistry, pp: 1-15.

34. Swidsinski A, Dörffel Y, Loening-Baucke V, Gille C, Reißhauer A, et al. (2017) Impact of humic acids on the colonic microbiome in healthy volunteers. Observational Study World J Gastroenterol 23(5): 885-890.

35. Mudroňová D, Karaffová V, Pešulová T, Koščová J, Cingelová-Maruščáková I, et al. (2020) The effect of humic substances on gut microbiota and immune response of broilers. Food and Agricultural Immunology 31(1): 137-149.

36. Stern N, Mejia J, He S, Yang Yu, Ginder-Vogel M, et al. (2018) Dual Role of Humic Substances As Electron Donor and Shuttle for Dissimilatory Iron Reduction. Environ Sci Technol 52(10): 5691-5699. 